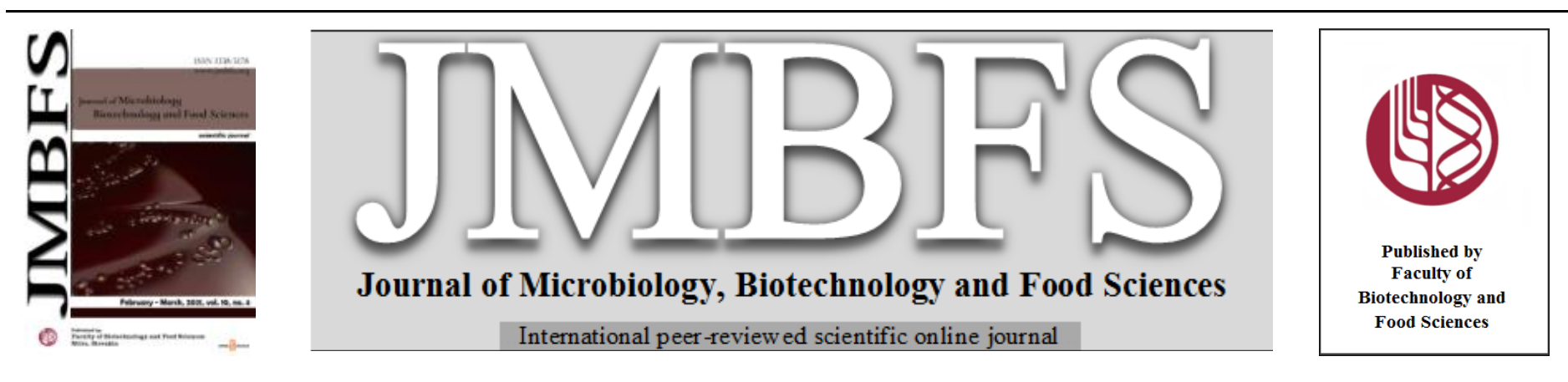

\title{
STUDY OF INHIBITION OF YEASTS, LACTIC AND ACETIC BACTERIA USING SILVER PARTICLES
}

\author{
Klara Chvalinova, Radim Holesinsky, Lenka Sochorova, Mojmir Baron, Jiri Sochor
}

Address(es): Assoc. Prof. Ing. Jiri Sochor, Ph.D.

Department of Viticulture and Enology, Faculty of Horticulture, Mendel University in Brno, Valticka 337, 69144 Lednice, Czech Republic.

*Corresponding author: jiri.sochor@mendelu.cz

doi: 10.15414/jmbfs.2021.10.4.581-585

\section{ARTICLE INFO}

Received 7. 4. 2020

Revised 2. 10. 2020

Accepted 2. 10. 2020

Published 1. 2. 2021

\section{Regular article}

OPEN $\partial_{\text {ACCESS }}$

\begin{abstract}
This paper deals with a study of the inhibition of microorganisms occurring in grape must and wine, using silver in the form of nanoparticles and colloidal solution. Pure cultures of yeasts Saccharomyces cerevisiae and Brettanomyces bruxellensis, lactic acid bacteria Lactobacillus brevis, Pediococcus damnsosus and acetic acid bacteria Acetobacter aceti and Gluconobacter oxydans were used for the experiments. Attention was primarily focused on monitoring changes in carbohydrate processing, namely glucose, fructose, sucrose, maltose, mannitol, galactose, trehalose, and B-glucosidase activity. These biochemical determinations have shown limitations in carbohydrate processing, particularly sucrose in yeasts, and fructose, glucose and sucrose in bacteria. The effects of silver have also been observed in natural microflora found in grape must from Chardonnay and Hibernal. Colloidal silver at concentrations 40, 70 and $100 \mathrm{ppm}$ and silver nanoparticles at concentrations 70,150 and $250 \mathrm{ppm}$ were used for inhibition. A plate method was used to determine the number of viable colonies. With an increasing concentration of applied substances, the growth of both yeasts and bacteria was strongly inhibited, as indicated by the numbers of colonies cultivated from the must. Yeast growth was inhibited by the lowest concentration - (70 ppm) by up to $72 \%$ and bacterial growth by up to $75.5 \%$.
\end{abstract}

Keywords: silver nanoparticles, colloidal silver, wine, yeast, lactic acid bacteria, acetic acid bacteria

\section{INTRODUCTION}

Owing to its antimicrobial properties (Mijnendonckx et al., 2013), silver has been a frequent subject of interest in recent decades. Numerous studies have been conducted to investigate the inhibitory effects of various forms of silver and the mechanisms of action against model pathogenic bacteria, most commonly Escherichia coli (Choi et al., 2018), Staphylococcus aureus (Kang et al., 2019), Pseudomonas aeruginosa (Salomoni et al., 2017), and also against yeast, the most common representative of which is Saccharomyces cerevisiae (Kudrinskiy et al., 2014).

The number of studies dealing with the application of silver to wine microorganisms is negligible. Nevertheless, the inhibitory effects are observed with colloidal silver (Izquierdo-Cañas $\boldsymbol{e t}$ al., 2012) as well as with silver nanoparticles (García-Ruiz et al., 2015).

In the process of fermentation, saccharides are utilised by yeasts in several steps. It begins with glycolysis, where hexoses are converted to pyruvate, which is further decarboxylated to acetaldehyde, and this is reduced to alcohol. Glucose is preferred to fructose for fermentation, but yeasts $S$. cerevisiae are capable of processing galactose, sucrose, maltose, trehalose, melibiose, raffinose, melezitose and starch (Zimmermann and Entian 1997). Lactic acid bacteria process carbohydrates into lactate, and eventually also ethanol, acetate and $\mathrm{CO}_{2}$. LAB observed by us can utilise arabinose, fructose, glucose, maltose, mannose, melibiose, ribose, raffinose and sucrose (Berlowska et al., 2016; Atuña and Martinez-Anaya, 1993).

Acetic acid bacteria form acetic acid from ethanol, but they oxidise glucose to gluconic acid. However, the AABs used in this study also oxidise other carbohydrates - arabinose, fructose, sucrose, galactose, mannose, ribose, sorbose and xylose (De Ley et al., 1984). The ability to process particular saccharides depends not only on the genus but also on the species and strain of microorganisms.

The aim of this study is to confirm the inhibitory effects of silver particles in the form of a colloidal solution and nanoparticles against microorganisms typical for wine production - yeast, lactic acid bacteria and acetic acid bacteria.

\section{MATERIALS AND METHODS}

\section{Microorganisms}

Pure cultures of microorganisms in the form of lyophilizates were used in laboratory experiments. The microorganisms Saccharomyces cerevisiae (CCM 8191), Lactobacillus brevis (CCM 1815), Pediococcus damnosus (CCM 2465), Acetobacter aceti (CCM 3620T) and Gluconobacter oxydans (CCM 3618) were obtained from the Czech Collection of Microorganisms. Yeasts, Brettanomyces bruxellensis, were isolated from wine. The lyophilisates of the microorganisms were activated by adding $0.3 \mathrm{~mL}$ of distilled water, allowed to recover for 15 minutes, and then the suspensions were transferred to Petri dishes onto the appropriate agar. The suspensions thus prepared were grown at $25^{\circ} \mathrm{C}$ for 24 hours. Yeasts were cultured on GYP agar (peptone 10 g.L.- , yeast extract g. $\mathrm{L}^{-1}$, dextrose g. $\mathrm{l}^{-1}$, agar g. $\mathrm{L}^{-1}$, HiMedia); lactic acid bacteria (LAB) were cultured on MRS agar (glucose 20 g.L. $\mathrm{L}^{-1}$, ammonium hydrogen citrate g.L $\mathrm{L}^{-1}$, potassium hydrogen phosphate $2 \mathrm{~g} . \mathrm{L}^{-1}$, magnesium sulfate $0.1 \mathrm{~g} . \mathrm{L}^{-1}$, manganese sulfate 0.05 g. $\mathrm{L}^{-1}$, meat extract 5 g. $\mathrm{L}^{-1}$, sodium acetate $5 \mathrm{~g} . \mathrm{L}^{-1}$, peptone $10 \mathrm{~g} . \mathrm{L}^{-1}$, yeast extract $5 \mathrm{~g} . \mathrm{L}^{-1}$, agar $12 \mathrm{~g} . \mathrm{L}^{-1}$, HiMedia) and acetic acid bacteria (AAB) were cultured on Acetobacter agar (meat peptone 3 g.L. $\mathrm{L}^{-1}$, yeast extract 5 g.L. $\mathrm{L}^{-1}$, mannitol $25 \mathrm{~g} . \mathrm{L}^{-1}$, agar 15 g.L.-1, HiMedia).

\section{Chemicals}

Colloidal silver in concentration of 100 ppm (Rulcotherapy, Czech Republic) in the form of an aqueous solution, and silver nanoparticles in concentration of 250 $\mathrm{ppm}$, with particle sizes ranging from 6 to $12 \mathrm{~nm}$ (Nano-BioTech, Poland). Lower concentrations of solutions were achieved by dilution with distilled water.

\section{Determination of saccharides consumption and $\beta$-glucosidase activity}

$30 \mathrm{ml}$ of sterile $0.9 \%$ saline was pipetted into a conical flask, a sufficient number of microorganisms (to a degree of turbidity of $2 \mathrm{McF}$, about $6 \times 108 \mathrm{CFU} / \mathrm{ml}$ ) were transferred into the solution with a sterile loop and mixed well. The resulting suspension was then pipetted into prepared microtiter plates with a desiccant (Erba Lachema, Czech Republic). $300 \mu$ Lof suspension was placed in wells without the use of silver particles (control) or $290 \mu \mathrm{L}$ of suspension and 10 $\mu \mathrm{L}$ of silver particles. Plates thus prepared, were loaded into a photometer 
(Multiskan TM FC Microplate Photometer, Thermo Fisher Scientific, USA) and the individual absorbances were measured. Wavelengths varied based on the used test, i.e. $595 \mathrm{~nm}$ for yeasts (CandidaScreen kit) and $405 \mathrm{~nm}$ for $\mathrm{LAB}$ and $\mathrm{AAB}$ (ANAEROtest $23 \mathrm{kit}$ for $\mathrm{LAB}$ and NEFERMtest 24 kit for AAB). The temperature during the measurement was $30^{\circ} \mathrm{C}$, the number of measurements was 96 , with a measurement interval of 15 minutes and with shaking for 20 seconds at the beginning of the interval.

\section{Basic must analysis}

Before fermentation, basic characteristics were determined - sugar amount using a digital refractometer (Atago, Japan), $\mathrm{pH}$ using a laboratory $\mathrm{pH}$ meter (inoLabß $\mathrm{pH}$ 7110, WTW, Czech Republic), titratable acids content, and yeast assimilable nitrogen (YAN) with an ALPHA II automatic analyser (Bruker, USA).

\section{Determination of microbial stability of must}

$500 \mathrm{ml}$ of Hibernal and Chardonnay grape must was transferred to conical flasks and $10 \mathrm{ml}$ of silver nanoparticles at $10,70,150$ or $250 \mathrm{ppm}$ or colloidal silver at $10,40,70$ or $100 \mathrm{ppm}$ were added to all flasks (except the control). After 24 hours at $20^{\circ} \mathrm{C}$, all variants were shaken and diluted $10,000 \mathrm{x}$ in tubes $(1 \mu \mathrm{L}$ of must was added to $9.999 \mathrm{~mL}$ of sterile $0.9 \%$ saline). To determine microbial stability, the prepared suspensions were applied to selective agars $-1 \mathrm{~mL}$ of each variant was transferred to $\mathrm{GKCH}$ agar (chloramphenicol prevented bacterial growth), MRS agar (for LAB growth) and Acetobacter agar (for AAB growth). After 48 hours of cultivation, grown colonies were counted.

\section{RESULTS}

The results are divided into two parts. In the first part are presented absorbance changes in carbohydrate processing, in the second part microbial stability is studied.

\section{Biochemical determination}

Monitoring of carbohydrate consumption and $\beta$-glucosidase activity in studied microorganisms was performed by observing absorbance changes. From the results of this determination, it can be concluded that the processing of saccharides is influenced, especially in bacteria (LAB and AAB), but the yeasts are not much affected. Figure 2 shows the absorbance values of the studied cultures after 24 hours.

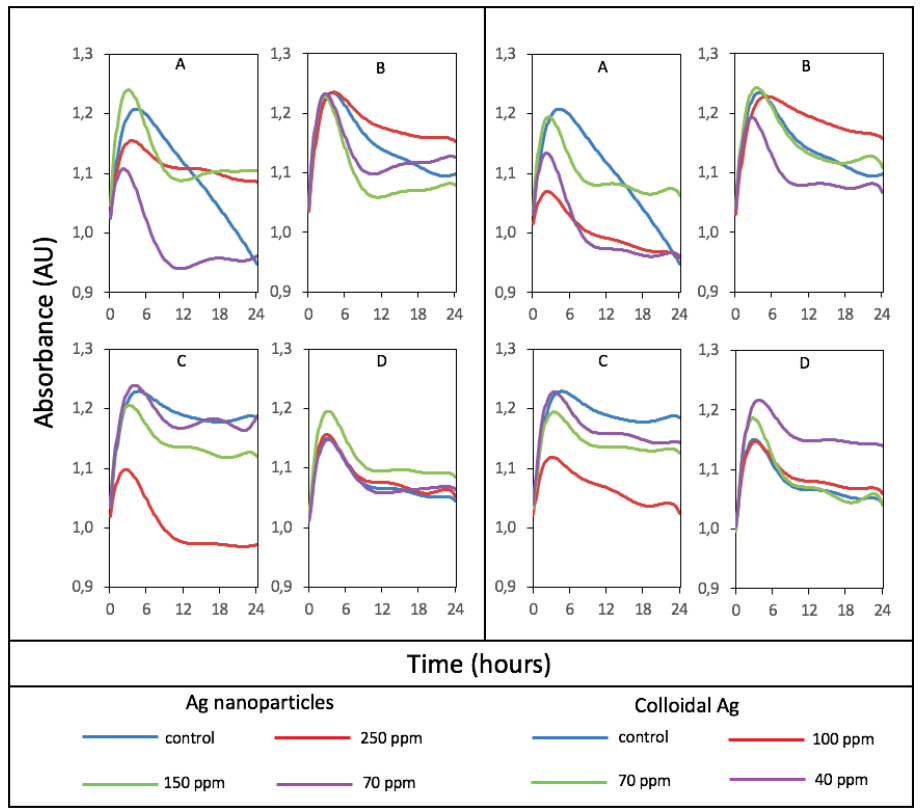

Figure 1 Absorbance changes in carbohydrate processing by $S$. cerevisiae yeas over 24 hours depending on the concentration of colloidal silver and AgNPs. (A) trehalose, (B) galactose, (C) maltose, (D) sucrose.

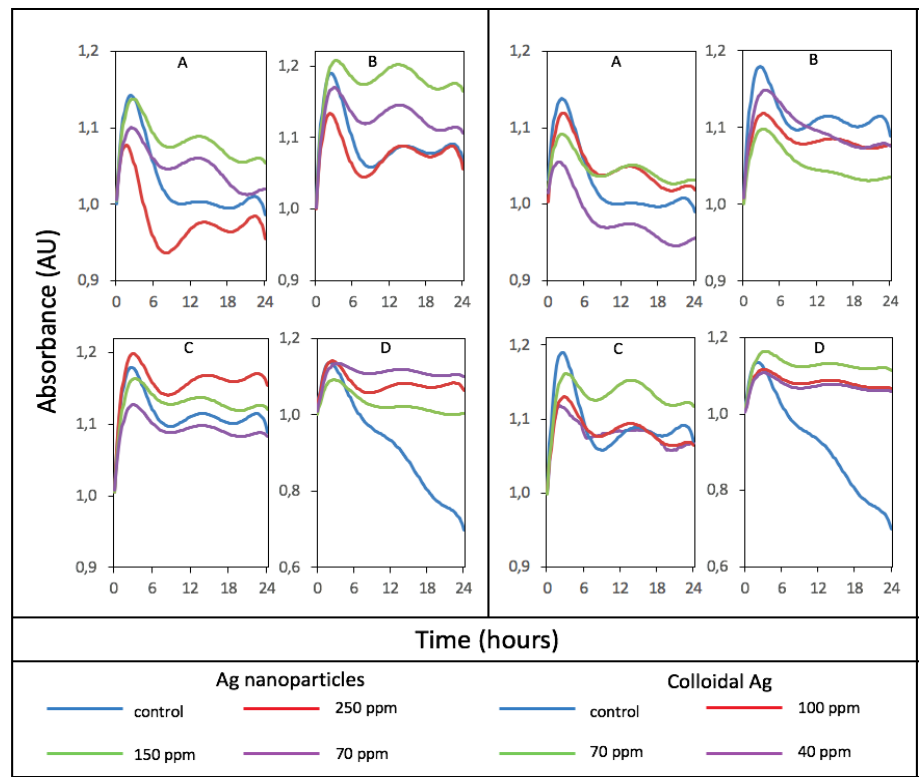

Figure 2 Absorbance changes in carbohydrate processing by B. bruxellensis yeast over 24 hours depending on the concentration of colloidal silver and AgNPs. (A) trehalose, (B) galactose, (C) maltose, (D) sucrose.

Figures 1 and 2 show changes in carbohydrate processing over time in yeast $S$ cerevisiae and B. bruxellensis, both under the action of colloidal silver and AgNPs. The observed changes were in the fermentation intensity of trehalose, galactose, maltose and sucrose, due to the ability of selected yeasts to ferment these carbohydrates. In the case of $S$. cerevisiae (Figure 1), there were visible changes in maltose processing. There was a clear inhibition using both colloida silver and AgNPs. For B. bruxellensis (Figure 2), both types of silver particles had visibly altered the course of fermentation only with sucrose.

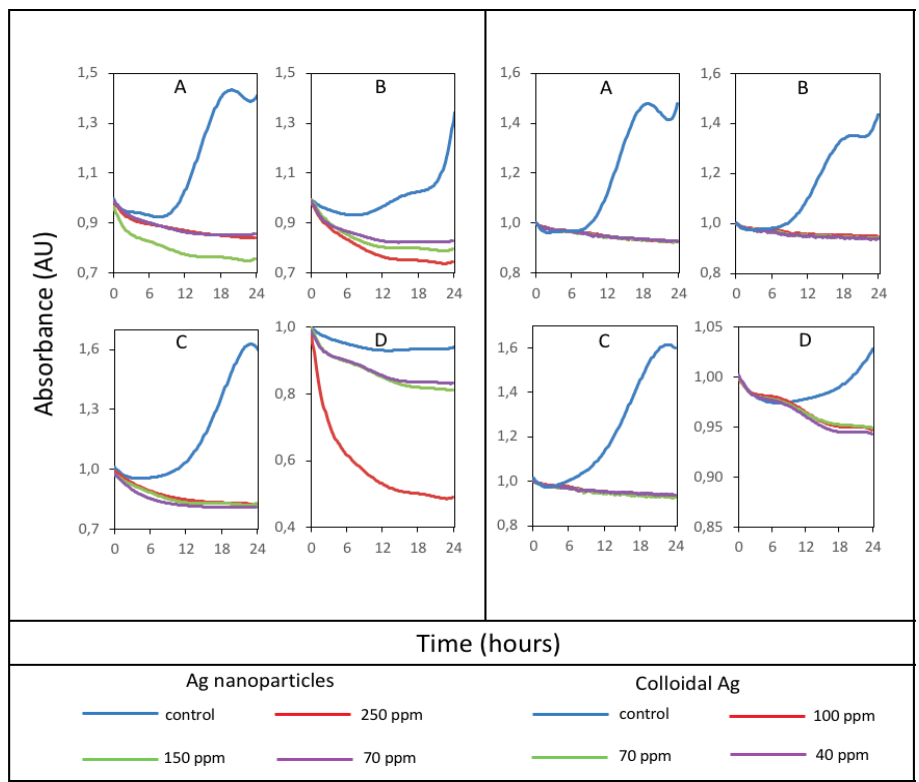

Figure 3 Absorbance changes in carbohydrate processing by L. brevis bacteria over 24 hours depending on the concentration of colloidal silver and AgNPs. (A) fructose, (B) glucose, (C) maltose, (D) sucrose.

L. brevis, respective its metabolic processes, was inhibited by both types of silver particles used (Figure 3). Compared with controls, there was a change in all carbohydrates. Control samples showed an increase in absorbance, whereas the variants using colloidal silver and AgNPs tended to decrease due to the strong inhibition caused by the application of silver particles. The inhibition rate corresponds with the concentration of silver particles applied. 


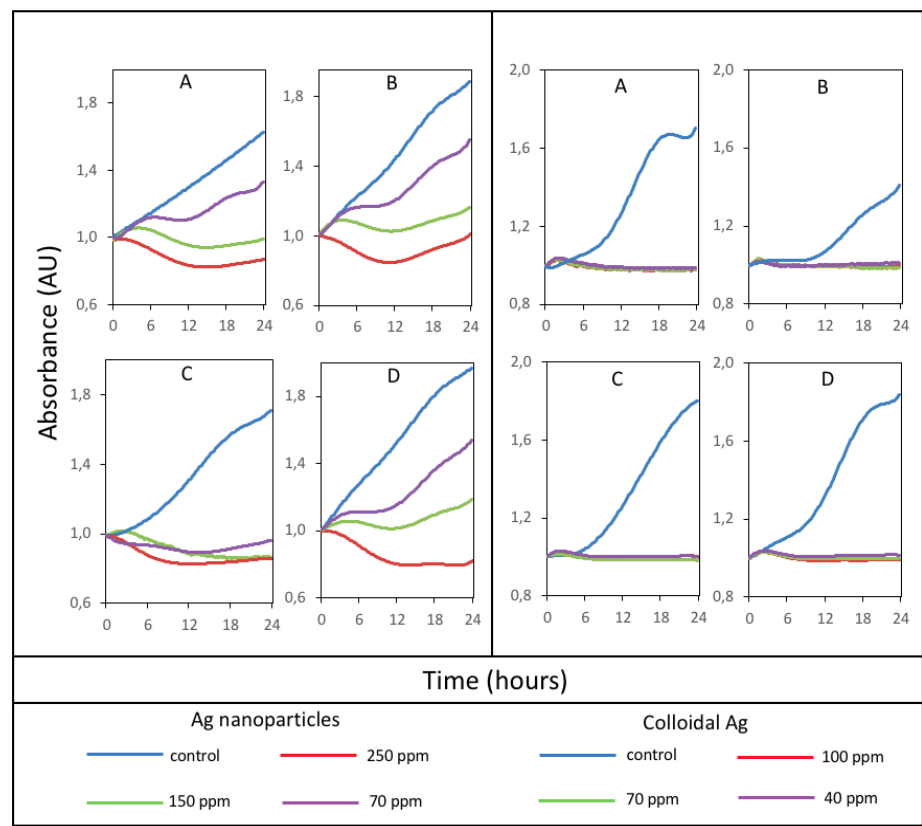

Figure 4 Absorbance changes in carbohydrate processing by $P$. damnosus bacteria over 24 hours depending on the concentration of colloidal silver and AgNPs. (A) fructose, (B) glucose, (C) maltose, (D) sucrose.

A representative of lactic acid bacteria, $P$. damnosus, was inhibited by al concentrations of both silver particles (Figure 4). The rate of inhibition of silver nanoparticles was concentration-dependent - the higher the concentration, the more the processing was limited. In contrast, colloidal silver inhibition was not concentration-dependent - the lowest concentration used avoided processing of all carbohydrates almost identically to the highest concentration.

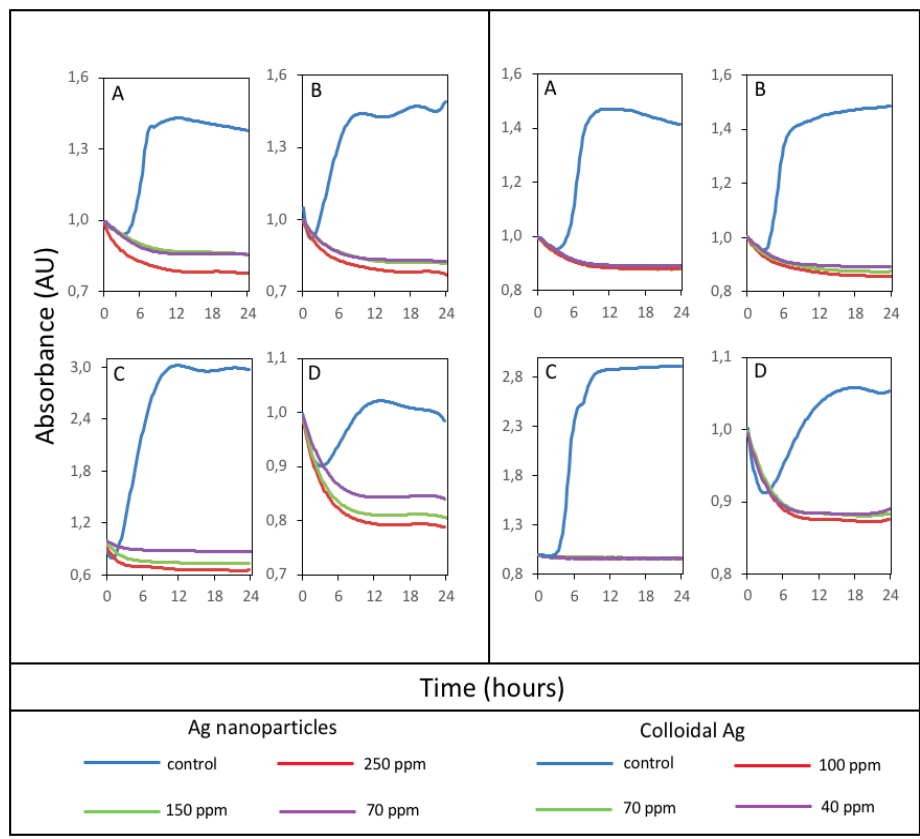

Figure 5 Absorbance changes in carbohydrate processing by A. aceti bacteria over 24 hours depending on the concentration of colloidal silver and AgNPs. (A) mannitol, (B) sucrose, (C) $\beta$-glucosidase activity, (D) galactose.

In Figure 5, we can see the effect of silver particles on acetic acid bacteria $A$. aceti, where processing of mannitol, sucrose, galactose, and $\beta$-glucosidase enzyme activity were observed. All processing and $\beta$-glucosidase activity were inhibited by both colloidal solution and nanoparticles. All controls showed an increase in absorbance, i.e. an increase in cell mass. Inhibition was the most pronounced at the highest concentrations of both particle types. Nevertheless, the differences in inhibitory effects among concentrations were not significant in this instance, given the absorbance values of the controls.

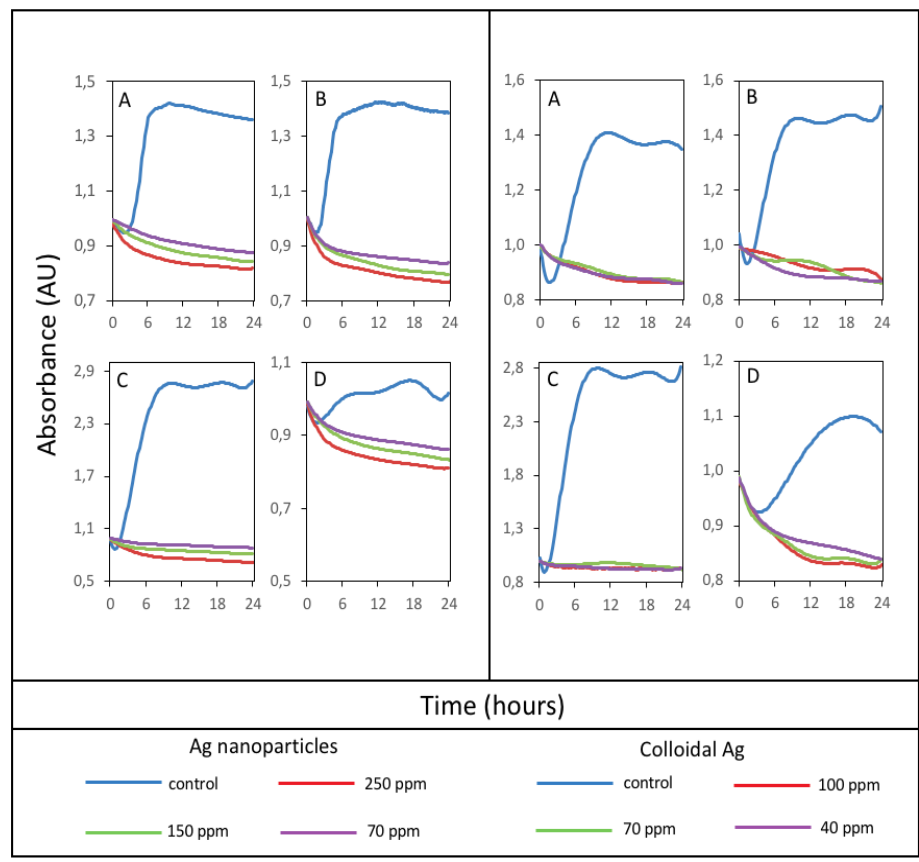

Figure 6 Absorbance changes in carbohydrate processing by G. oxydans bacteria over 24 hours depending on the concentration of colloidal silver and AgNPs. (A) mannitol, (B) sucrose, (C) $\beta$-glucosidase activity, (D) galactose

The second $\mathrm{AAB}$ representative G. oxydans showed the same results as A. aceti. Again, all carbohydrate processing and $\beta$-glucosidase activity were inhibited, with differences in concentrations in terms of inhibition rates being minimal, as can be seen in Figure 6.

\section{Determination of microbial stability}

The growth of colonies of yeasts, lactic and acetic bacteria, naturally present in must and often undesirable, was observed. Both types of particles were compared to the control and the results show significant inhibitory effects. Results are expressed as the average of three measurements.

Must was analysed for basic must parameters (sugar amount, $\mathrm{pH}$, total acidity and yeast assimilated nitrogen - YAN) and the measured values are shown in Table 1 .

Table 1 Basic must parameters

\begin{tabular}{lc}
\hline Sugar amount & $15,8^{\circ} \mathrm{NM}$ \\
\hline $\mathrm{pH}$ & 3,62 \\
\hline Total acidity & $6,0 \mathrm{~g} . \mathrm{L}^{-1}$ \\
\hline YAN & $417,0 \mathrm{mg} \cdot \mathrm{L}^{-1}$ \\
\hline
\end{tabular}

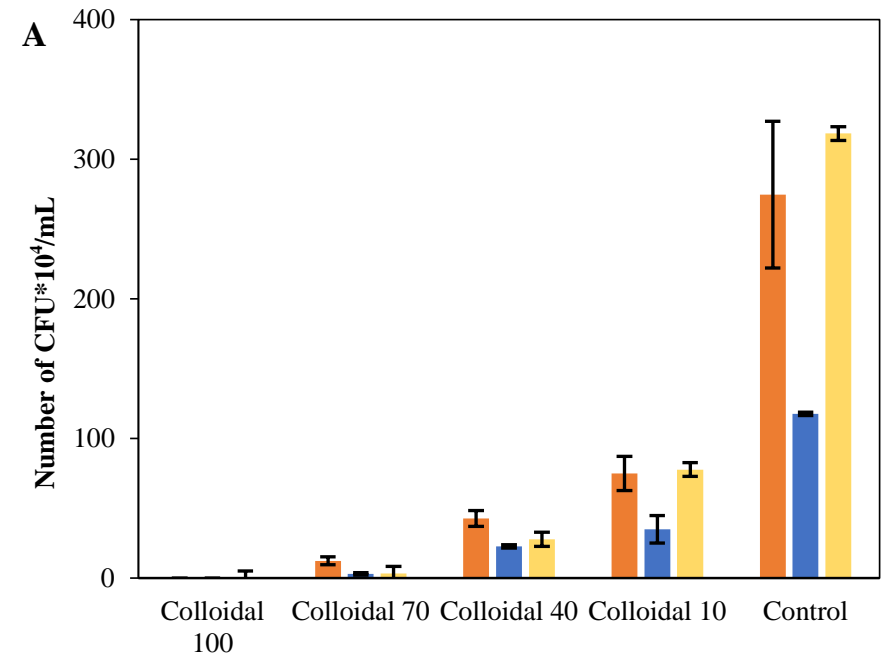




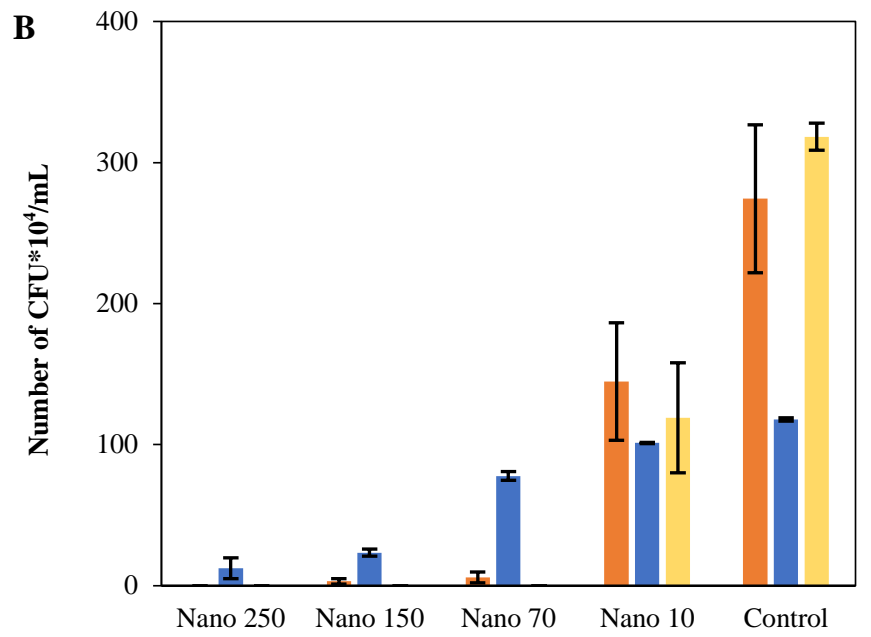

Figures 7 Number of grown CFUs depending on particle type (A-colloidal silver, B-nanoparticles of silver) and its concentration. Orange bars indicate yeast growth, blue bars indicate $\mathrm{AAB}$ growth and yellow bars indicate $\mathrm{LAB}$ growth. Light grey lines indicate guidelines.

Figures $7 \mathrm{~A}$ and $7 \mathrm{~B}$ show the number of yeasts and acetic and lactic acid bacteria colonies after application of silver nanoparticles at concentrations $10,70,150$ or $250 \mathrm{ppm}$, and colloidal silver at concentrations $10,40,70$ or $100 \mathrm{ppm}$, and a control variant. The inhibitory effects of the particles depend on the concentration of the solution. In the case of yeasts, $100 \%$ inhibition occurred at the highest concentrations of both types of silver particles. A concentration of silver nanoparticles at $150 \mathrm{ppm}$ inhibited the growth of yeasts by almost $99 \%$, and a concentration at $70 \mathrm{ppm}$ by $98 \%$. The weakest concentration, $10 \mathrm{ppm}$, was sufficient to inhibit more than $47 \%$ of the yeasts.

At the highest concentration of colloidal silver, all yeasts, acetic and lactic acid bacteria contained in the must were inhibited. The most sensitive to silver nanoparticles appears to be lactic acid bacteria, which were absolutely inhibited by the three highest concentrations $(70,150$ and $250 \mathrm{ppm})$. However, even the lowest concentration, $10 \mathrm{ppm}$, reduced growth by $62 \%$, so was effective compared with the colony growth of the control. In contrast, acetic acid bacteria were the least sensitive to AgNPs in this experiment. Even at the highest concentration, their growth was not completely ceased. The lowest concentration, $10 \mathrm{ppm}$, limited growth by only $11 \%$. It was also the least represented group of microorganisms in the grape must. As the concentration increased, the inhibitory power of both types of silver particles also increased, with colloidal silver generally showing stronger inhibitory effects.

The known inhibitory effect of silver was confirmed in this study by two methods - applying the particles to the must to inhibit the natural microflora and then determining the number of viable colonies, and biochemical determination of carbohydrate processing by pure cultures of yeasts ( $S$. cerevisiae, $B$. bruxellensis), LAB (L. brevis, P. damnosus) and AAB (A. aceti, G. oxydans).

\section{DISCUSSION}

Owing to its antimicrobial effects, silver is still a frequent subject of research (Oves et al., 2018; Pugazhendhi et al., 2018; Shanmuganathan et al., 2018) Given the presence of a wide range of microorganisms in grape must and wine and the lack of studies on this topic, this research has explored the possibility of inhibiting microorganisms using silver and eliminating their effects on wine. After the application of colloidal silver to the must, both yeasts and lactic acid and acetic acid bacteria, naturally occurring in the wine, were inhibited. Although comparisons with the wine control are missing, Izquierdo-Cañas (2012), when comparing $\mathrm{SO}_{2}$ and colloidal silver in terms of antimicrobial effects against yeasts, $\mathrm{LAB}$ and $\mathrm{AAB}$ in white and red wine, states that $1 \mathrm{~g}$ of colloidal silver complex (CSC) per kg of grapes shows the same degree of control over microbial development as sulphur dioxide at a dose of $50 \mathrm{mg} . \mathrm{kg}^{-1}$ (Izquierdo-Cañas et al. 2012). In the case of nanoparticles, the inhibitory effect against all investigated microorganisms was also confirmed, with the most pronounced effect being observed in lactic acid bacteria, where the lowest concentration of $10 \mathrm{ppm}$ reduced LAB growth by $62 \%$. To inhibit $50 \%$ of Lactobacillus lactic acid bacteria in the stationary phase of growth (IC50) used by García-Ruiz in his research (García-Ruiz et al., 2015), concentrations of $88-380 \mu \mathrm{g} \cdot \mathrm{mL}^{-1} \mathrm{Ag}$ nanoparticles stabilised with polyethelynglycol (PEG-Ag NPs) and 17-65 $\mu \mathrm{g} . \mathrm{mL}$ ${ }^{1} \mathrm{Ag}$ nanoparticles stabilised with glutathione (GLU-Ag NPs) were sufficient, depending on the bacterial strain. The IC 50 for the potassium metabisulfite used for comparison was 310-820 $\mu \mathrm{g} \cdot \mathrm{mL}^{-1}$. Observing $\mathrm{AAB}$ under the same conditions gave similar results - IC 50 for PEG-Ag NPs $30-32 \mu \mathrm{g} \cdot \mathrm{mL}^{-1}$, for GLU-Ag NPs 29-30 $\mu \mathrm{g} \cdot \mathrm{mL}^{-1}$, and for $\mathrm{K}_{2} \mathrm{~S}_{2} \mathrm{O}_{5} 470-480 \mu \mathrm{g} \cdot \mathrm{mL}^{-1}$. According to
Garde-Cerdán (2013), the addition of colloidal silver to wine has the same effect as $\mathrm{SO}_{2}$ on the control of yeasts and lactic acid bacteria growth during vinification. The growth of acetic acid bacteria is controlled more effectively by the impact of colloidal silver. However, despite the apparent inhibitory effect, a dose of $1 \mathrm{~g} \cdot \mathrm{kg}^{-1}$ was not sufficient to completely stop the growth of microorganisms. The best solution for growth control seems to be a combination of colloidal silver and sulphur dioxide (Garde-Cerdán et al., 2013). These results indicate a higher sensitivity of acetic bacteria to colloidal silver, which may be due to simpler cell wall construction as $\mathrm{G}^{+}$bacteria (Madigan and Martinko 2005; Baron 1996). They are therefore inconsistent with the results of this study, where lactic acid bacteria were the most sensitive microorganisms. Differences in minimum inhibitory concentrations (MIC) for Gram-positive (Bacillus subtilis) and Gram-negative bacteria (Escherichia coli, Pseudomonas aeruginosa) are also confirmed by Escárcega-González et al. (2018), whose results correspond with ours. The MIC of green-synthesised nanoparticles produced by $\mathrm{G}^{-}$bacteria $E$. coli and $P$. aeruginosa were $62.5 \mathrm{ppm}$ and $15.6 \mathrm{ppm}$, but for representatives of $\mathrm{G}^{+}$bacteria the MIC was only $0.45 \mathrm{ppm}$. This supports the theory of higher sensitivity of Gram-positive bacteria. Model bacteria Escherichia coli (Gram-negative) and Staphylococcus aureus (Gram-positive) react to silver nanoparticles with an average size of $20 \mathrm{~nm}$ at various concentrations by limiting growth. Inhibition of $50 \%$ of bacteria required concentration of $11.89 \mathrm{mg} . \mathrm{L}^{-1}$ for $E$. coli and $6.98 \mathrm{mg} . \mathrm{L}^{-1}$ for $S$. aureus (Kaweeteeravat et al., 2017). AgNPs dose-dependent was also the formation of reactive oxygen species (ROS), which is one of the major manifestations of AgNPs toxicity (Ivask et al., 2014). At the same time, the study showed that after pre-exposure of bacteria to silver nanoparticles, they adapt to silver and create protective mechanisms. The method of biochemical determination of processed carbon sources used in this research was applied for the first time. Effects of silver on the processing of carbohydrates, or the activity of enzymes in the case of yeasts, is minimal, and even the highest concentration used in this study, 100 ppm, has no significant effect. Conversely, lactic acid and acetic acid bacteria are inhibited almost equally by all concentrations. Control curves showed an upward trend in almost all cases over 24 hours, which can be attributed to the multiplication of bacteria in the presence of individual markers (carbohydrates). The curves of variants with silver particles have decreased in many cases. Apparently, there has been a change in colour, but not due to the processing of carbohydrates. This phenomenon may be due to a change in $\mathrm{pH}$ or a high cultivation temperature $\left(30^{\circ} \mathrm{C}\right)$. Monitoring of metabolic pathways affected by the presence of metals is also a unique research topic (Oliveira et al., 2012; Das, 2012). However, changes in carbohydrate concentrations have been confirmed by several studies. The action of antimicrobial agents, including silver nanoparticles, causes release of trehalose and glucose, both outside and inside Candida albicans cells (Kim et al., 2009). Other metals also cause a decrease in glucose absorption, such as nickel and uranium, as confirmed by Steveninck and Rothstein (1965)

\section{CONCLUSION}

This study focused on the inhibitory effect of colloidal silver and silver nanoparticles against yeasts, lactic and acetic acid bacteria, both in the forms of pure cultures and wild, naturally occurring cultures. The aim of this study was to monitor the effects of silver particles and confirm their possible use as an inhibitory agent. Results of the methods we applied confirmed these effects, the silver inhibited the diverse natural grape must culture, but also representatives of lactic and acetic acid bacteria in the form of pure cultures.

The only problematic species seemed to be pure culture yeasts, for which biochemical determination did not support this hypothesis. An important aspect of the use of silver is its negative impact on human health, thus, it is desirable to focus on the possibility of its removal from wine and long-term exposure to the small concentrations required to inhibit microorganisms in future studies.

Acknowledgments: This paper was supported by the project INTER-COST LTC 18002 and by project IGA - ZF/2020 - DP004.

\section{REFERENCES}

Ansari, M.A., Khan, H.M., Khan, A.A., Ahmad, M.K., Mahdi, A.A., Pal, R., Cameotra, S.S. (2014). Interaction of silver nanoparticles with Escherichia coli and their cell envelope biomolecules. J. Basic Microbiol., 54(9), 905-915. http://dx.doi.org/10.1002/jobm.201300457

Atuña, B., Martinez-Anaya, M.A. (1993). Sugar uptake and involved enzymatic activities by yeast and lactic acid bacteria: their relationship with breadmaking quality. Int. J. Food Microbiol., 18(3), 191-200. http://dx.doi.org/10.1016/01681605(93)90044-H

Baron, S. (1996). Medical microbiology. $4^{\text {th }}$ edition, University of Texas Medical Branch, Galveston. ISBN-13: 978-0963117212.

Berlowska, J., Cieciura, W., Borowski, S., Dudkiewicz, M., Binczarski, M., Witonska, I., Otlewska, A., Kregiel, D. (2016). Simultaneous Saccharification and Fermentation of Sugar Beet Pulp with Mixed Bacterial Cultures for Lactic 
Acid and Propylene Glycol Production. Molecules, 21(10), 1380. http://dx.doi.org/10.3390/molecules21101380

Carlson, C., Hussain, S.M., Schrand, A.M., Braydich-Stolle, L.K., Hessl, K.L., Jones, R.L., Schlager, J.J (2008). Unique Cellular Interaction of Silver Nanoparticles: Size-Dependent Generation of Reactive Oxygen Species. J. Phys. Chem. B, 112(43), 13608-13619. http://dx.doi.org/10.1021/jp712087m

Das, D. 2012. Study on the Effect on Silver Nanoparticles on Growth and Certain Metabolic Activities of Saccharomyces cerevisiae. PhD dissertation, Gauhati University.

De Ley, J., Gillis, M., Swings, J. (1984). Family IV. Acetobacteraceae. In: Krieg, N.L. and Holt, J.G., Eds., Bergey's Manual of Systematic Bacteriology, Vol. 1, Williams \& Wilkins, Baltimore, 267-278.

Escárcega-Gonzáles, C. E., Garza-Cervantes, J.A., Vázquez-Rodríguez, A., Montelongo-Peralta, L.Z., Treviño-Gonzáles, M.T., Díaz Barriga Castro, E., Saucedo-Salazar, E.M., Chávez Morales, R.M., Regalado Soto, D.I., Treviño Gonzáles, F.M., Carrazco Rosales, J.L., Cruz, R.V., Morones-Ramírez, J.R. (2018). In vivo antimicrobial activity of silver nanoparticles produced via a green chemistry synthesis using Acacia rigidula as a reducing and capping agent. Int. J. Nanomedicine, 13, 2349-2363. http://dx.doi.org/10.2147/IJN.S160605

García-Ruiz, A., Crespo, J., López-de-Luzuriaga, J.M., Olmos, M.E., Monge, M., Rodríguez-Álfaro, M.P., Martín-Álvarez, P.J., Bartolome, B., Moreno-Arribas, M.V. (2015). Novel biocompatible silver nanoparticles for controlling the growth of lactic acid bacteria and acetic acid bacteria in wines. Food Control, 50, 613 619. http://dx.doi.org/10.1016/j.foodcont.2014.09.035

Garde-Cerdán, T., López, R., Garijo, P., Gónzales-Arenzana, L., Gutiérrez, A.R., López-Alfaro, I., Santamaría, P. (2013). Application of colloidal silver versus sulfur dioxide during vinification and storage of Tempranillo red wines. Aust. J. Grape Wine R., 20(1), 51-61. http://dx.doi.org/10.1111/ajgw.12050

Choi, O., Den, K.K., Kim, N., Ross Jr., L., Surampalli, R.Y., Hu, Z. (2008). The inhibitory effects of silver nanoparticles, silver ions, and silver chloride colloids on microbial growth. Water Res, 42(12), 3066-3074 http://dx.doi.org/10.1016/j.watres.2008.02.021

Choi, Y., Kim, H., Kim, K., Lee, B. (2018). Comparative toxicity of silver nanoparticles and silver ions to Escherichia coli. J. Environ. Sci., 60: 50-60. http://dx.doi.org/10.1016/j.jes.2017.04.028

Ivask, A., ElBadawy, A., Kaweeteerawat, C., Boren, D., Fischer, H., Ji., Z., Chang, C.H., Liu, R., Tolaymat, T., Telesca, D., Zink, J.I., Cohen, Y., Holden, P.A., Godwin, H.A. (2014). Toxicity mechanism in Escherichia coli vary for silver nanoparticles and differ from ionic silver. ACS Nano, 8(1), 374-386. http://dx.doi.org/10.1021/nn4044047

Izquierdo-Cañas, P.M., García-Romero, E., Huertas-Nebreda, B., Gómez-Alonso, S. (2012). Colloidal silver complex as an alternative to sulphur dioxide on $\begin{array}{llll}\text { winemaking. } & \text { Food } & \text { Control, } & \text { 23(1), }\end{array}$ http://dx.doi.org/10.1016/j.foodcont.2011.06.014

Kang, J., Dietz, M.Z., Hughes, K., Xing, M., Li, B. (2019). Silver nanoparticles present hich intracellular and extracellular killing against Staphylococcus aureus. J. Antimicrob Chemother. http://dx.doi.org/10.1093/jac/dkz053

Kaweeteeravat, C., Na Ubol, P., Sangmuang, S., Aueviriyavit, S., Maniratanachote, R. (2017). Mechanism of antibiotic resistance in bacteria mediated by silver nanoparticles. J. Toxicol. Environ. Health A, 80(23-24), 1276-1289. http://dx.doi.org/10.1080/15287394.2017.1376727

Kim, K.J., Sung, W.S., Suh, B.K., Moon, S.K., Choi, J.S., Kim, J.G., Lee, D.G. (2009). Antifungal activity and mode of action of silver nano-particles on Candida albicans. Biometals, 22(2), 235-242. http://dx.doi.org/10.1007/s10534008-9159-2

Kudrinskiy, A. A., Ivanov, A.Yu., Kulakovskaya, E.V., Klimov, A.I., Zherebin, P.M., Khodarev, D.V., Le, A., Tam, L.T., Lisichkin, L.V., Krutyakov, Yu.A (2014). The Mode of Action of Silver and Silver Halides Nanoparticles against Saccharomyces cerevisiae Cells. J. Nanopart., 2014(2), 1-7. http://dx.doi.org/10.1155/2014/568635

Madigan, M., Martinko, J. (2005). Brock biology of microorganisms. $11^{\text {th }}$ edition, Prentice Hall, Englewood Cliffs, NJ.

Mijnendonckx, K. Leys, N., Mahillon, J., Silver, S., Van Houdt, R. (2013).

Antimicrobial silver: uses, toxicity and potential for resistance. BioMetals, 26(4), 609-621. http://dx.doi.org/10.1007/s10534-013-9645-z

Oliveira, R.P., Basso, L.C., Junior, A.P., Penna, T.C, Del Borghi, M., Converti, A. (2012). Response of Saccharomyces cerevisiae to Cadmium and Nickel Stress: the Use of Sugar Cane Vinasse as a Potential Mitigator. Biol. Trace Elem. Res., 145(1), 71-80. http://dx.doi.org/10.1007/s12011-011-9156-0

Oves, M., Asiam, M., Rauf, M.A., Qayyum, S., Qari, H.A., Khan, M.S., Alam, M.Z., Tabrez, S., Pugazhendhi, I., Ismail, I.M.I. (2018). Antimicrobial and anticancer activities of silver nanoparticles synthesized from the root hair extract of Phoenix dactylifera. Mater. Sci. Eng. C Mater. Biol. Appl., 89, 429-443. http://dx.doi.org/10.1016/j.msec.2018.03.035

Pugazhendhi, A., Prabakar, D., Jacob, J.M., Karuppusamy, I., Saratale, R.G. (2018). Synthesis and characterization of silver nanoparticles using Gelidium amansii and its antimicrobial property against various pathogenic bacteria Microb. Pathog., 114, 41-45. http://dx.doi.org/10.1016/j.micpath.2017.11.013
Salomoni, R., Léo, P., Montemor. A.F., Rinaldi, B.G., Rodrigues, M. (2017). Antibacterial effect of silver nanoparticles on Pseudomonas aeruginosa Nanotechnol. Scie. Appl., 10, 115-121. http://dx.doi.org/10.2147/NSA.S133415 Shanmuganathan, R., MubarakAli, D., Prabar, D., Muthukumar, H., Thajuddin, N., Kumar, S.S., Pugazhendhi, A. (2018). An enhancement of antimicrobial efficacy of biogenic and ceftriaxone-conjugated silver nanoparticles: green approach. Environ. Sci. Pollut. Res. Int., 25(11), 10362-10370. http://dx.doi.org/10.1007/s11356-017-9367-9

Steveninck, J., Rothstein, A. (1965). Sugar Transport and Metal Binding in Yeast. J. Gen. Physiol., 49(2), 235-246. http://dx.doi.org/10.1085/igp.49.2.235

Zimmermann, F.K., Entian, K.D. (1997). Yeast sugar metabolism: biochemistry, genetics, biotechnology and applications. Lancaster PA: Technomic Publishing Company. ISBN: 1-56676-466-1. 